\title{
The new base excision repair pathway in mammals mediated by tyrosyl-DNA phosphodiesterase 1
}

\author{
N. A. Lebedeva, N. I. Rechkunova, O. I. Lavrik \\ Novosibirsk Institute of Chemical Biology and Fundamental Medicine, Siberian Branch of the Russian Academy of Sciences \\ 8, Akademika Lavrentieva Ave., Novosibirsk, Russian Federation, 630090 \\ nataleb@niboch.nsc.ru
}

\begin{abstract}
Human tyrosyl-DNA phosphodiesterase 1 (Tdp1) hydrolyzes the phosphodiester bond at a DNA 3' end linked to a tyrosyl moiety and has been implicated in the repair of Topoisomerase I (TopI)-DNA covalent complexes. TdpI can also hydrolyze other 3' end DNA alterations including 3' phosphoglycolate and 3' abasic (AP) sites, and exhibits the 3' nucleosidase activity indicating that it may function as a general 3' end-processing DNA repair enzyme. Recently we have shown a new Tdp1 activity generating DNA strand break with the 3' phosphate termini from the AP site. AP sites are formed spontaneously and are inevitable intermediates during base excision repair of DNA base damages. AP sites are both mutagenic and cytotoxic, and key enzymes for their removal are AP endonucleases. However, AP endonuclease independent repair, initiated by DNA glycosylases performing beta, delta-elimination cleavage of the AP sites, has been described in mammalian cells. Here, we describe another AP endonuclease independent repair pathway for removal of AP sites that is initiated by tyrosyl phosphodiesterase Tdp1. We propose that repair is completed by the action of a polynucleotide kinase, a DNA polymerase and finally a DNA ligase to seal the gap.
\end{abstract}

Keywords: base excision repair, AP site, tyrosyl-DNA phosphodiesterase 1.

Tyrosyl-DNA phosphodiesterase (Tdp1) was discovered as an enzymatic activity from Saccharomyces cerevisiae that specifically hydrolyzes the phosphodiester linkage between the O-4 atom of a tyrosine and a DNA 3' phosphate [1]. This type of linkage is typical for the covalent reaction intermediate produced upon Topoisomerase 1 (Top1) cleavage of one DNA strand. Tdp1 activity is not limited to the removal of Top1 adducts. Human Tdp1 can also hydrolyze other 3' end DNA alterations that are covalently linked to the DNA, indicating that it may function as a general 3' DNA phosphodiesterase and repair enzyme [2]. Oxidative damage at DNA ends (i. e. the termini of DNA single- or doublestrand breaks) or intermediates in the base excision repair process may represent substrates for Tdp 1 in vivo. For example, it is conceivable that Tdp1 acts on the $3^{\prime}$ phospho- $\alpha, \beta$-unsaturated aldehyde ( $\left.3^{\prime} \mathrm{dRP}\right)$ that results from $\beta$-elimination by the base-specific mammalian DNA glycosylases/AP lyases (for example, OGG1 or NTH1)

(c) Institute of Molecular Biology and Genetics, NAS of Ukraine, 2012
$[3,4]$. Also Tdp1 can remove the tetrahydrofuran moiety, a synthetic analogue of abasic (AP) site, from the $3^{\prime}$ end of DNA [5]. In addition, human Tdp1 possesses the 3 ' nucleosidase activity in which a single nucleoside is removed from 3' hydroxy terminated ribo- and deoxyribonucleosides [5].

The yeast enzyme was reported to be unable to cleave the DNA phosphate backbone, but it is possible that the assay used was not sensitive enough to detect this activity [6]. It has also been reported that yeast Tdp1 is capable of hydrolyzing DNA 5' phosphotyrosyl linkages [7], suggesting a possible role for the yeast enzyme in the repair of topoisomerase II covalent complexes, although such 5 ' processing activity has not been found for human Tdp1 [1, 8]. Notably, the human enzyme with 5 ' cleavage activity has recently been reported and referred to as Tdp2 (TTRAP) [9].

The 3' phosphate end generated by Tdp1 has to be hydrolyzed to a 3' hydroxyl in order to enable the following DNA repair. Polynucleotide kinase 3' phospha- 


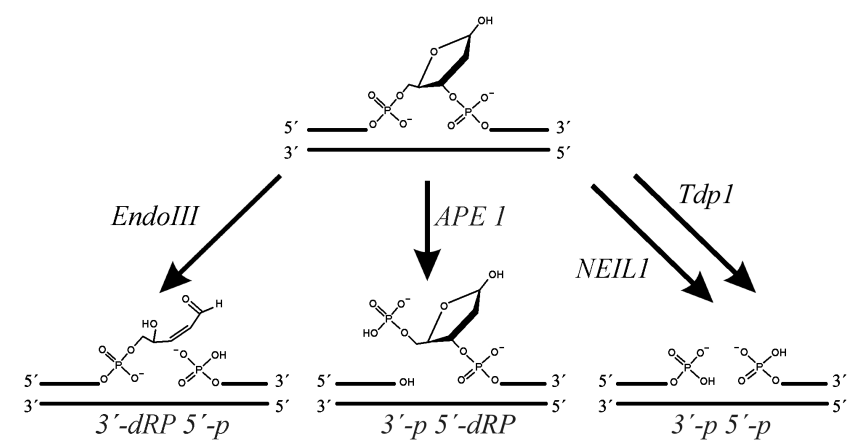

Fig. 1. Scheme of hydrolysis of the AP site in one strand of DNA duplex by different enzymes

tase (PNKP), a bifunctional enzyme with 5' kinase and 3 ' phosphatase activities, has been suggested as a reasonable candidate in human cells for the repair of these $3 '$ phosphate lesions. Tdp1 has been shown to exist in complex with PNKP in human cells $[10,11]$.

Quite recently we have shown a new activity of Tdp1 catalyzing cleavage of AP site with the formation of $3^{\prime}$ and 5' phosphate termini [12]. AP sites in cellular DNA arise as a result of excision of the oxidatively damaged bases by DNA glycosylases that initiate base excision repair (BER), or by spontaneous hydrolysis that generates several thousand AP sites per day in living cells $[3,13]$. The major enzyme in eukaryotic cells that catalyzes the cleavage of AP sites is apurinic/apyrimidinic endonuclease 1 (APE1). APE1 hydrolyses the phosphodiester bond on the 5' side of AP sites (Fig. 1).

Bifunctional DNA glycosylases that excise oxidized bases also possess an intrinsic lyase activity, cleaving the DNA at the resultant AP sites [14]. These DNA glycosylase/AP lyases belong to two broad classes of enzymes according to their reaction mechanism. Escherichia coli $\mathrm{Nth}$ is the representative of one class that utilizes an internal lysine as the active site nucleophile and cleaves the DNA strand at the AP site by $\beta$ elimination, generating a $3^{\prime} \mathrm{dRP}$ at the strand break [15]. In contrast, another class of mammalian DNA glycosylases, belonging to the family of $E$. coli Nei and Fpg (named Neilike (NEIL)) catalyzes $\beta \delta$ elimination at the AP site and removes a deoxyribose residue to produce a 3 ' phosphate terminus at the DNA strand break [16].

However, the human Tdp1 protein also can initiate repair of AP sites [12]. We have shown that the human Tdp1 can initiate repair of AP sites generating DNA strand break with the $3^{\prime}$ and $5^{\prime}$ phosphate termini from the AP site [12], therefore it can function in a fashion similar to NEIL1 in the APE-independent BER pathway. 3' phosphate ends generated by Tdp1 are efficiently removed by PNKP to produce a 3'-hydroxyl, which can be processed further and repaired by DNA polymerases and ligases [17-19]. Tdp1 is known to interact with base excision repair proteins: DNA polymerase beta (Pol $\beta$ ), XRCC1, poly(ADPribose)polymerase 1 (PARP1) and DNA ligase III [2, 10, 20, 21]. So, the repair of AP site initiated by Tdp1 fully restored the intact DNA and generated the products of the expected lengths at each intermediate stage. In summary, the human Tdp1 protein can initiate APE1-independent repair of AP sites and 3' dRP termini that expands the ability of the BER process. To study an ability of Tdp1 to process the 3' dRP moiety AP DNA was first incubated with Endo III. Following incubation of this product with Tdp1 results in an oligonucleotide with 3' phosphate, which can be removed by PNKP. Thus, Tdp1 is able to remove the 3' dRP that allows realizing the APE1independent pathway of BER where AP sites are cleaved by bifunctional DNA glycosylases via the $\beta$ elimination mechanism.

Recently Tdp1 contributions in BER process in mitochondria [22] and yeast Schizosaccharomyces pombe [23] have been proposed. Nilsen with coworkers [23] described also AP endonuclease independent repair pathway for removal of the AP sites in S. pombe that is initiated by bifunctional DNA glycosylase, Nth1 and followed by cleavage of the baseless sugar residue by tyrosyl phosphodiesterase Tdp1. Nth1 initiates the repair by $\beta$-elimination of the AP site, whereas Tdp 1 cleaves the $3^{\prime}$ dRP to generate a $3^{\prime} P$ that can be further processed by phosphatases. This newly identified branch of the BER pathway with Tdp1 working downstream of Nth1, seems to function as an important backup repair pathway in the absence of Apn2 in the repair of the AP sites in S. pombe.

In summary, these authors showed that Tdp1 played a more general role in DNA repair than only removal of Top1-mediated DNA damage. Tdp1 can be placed in a new branch of the BER pathway working downstream of Nth1 by processing the 3' dRP left after Nth1 cleavage.

As a repair enzyme, Tdp1 exhibits considerable versatility in removing a diverse spectrum of adducts from 


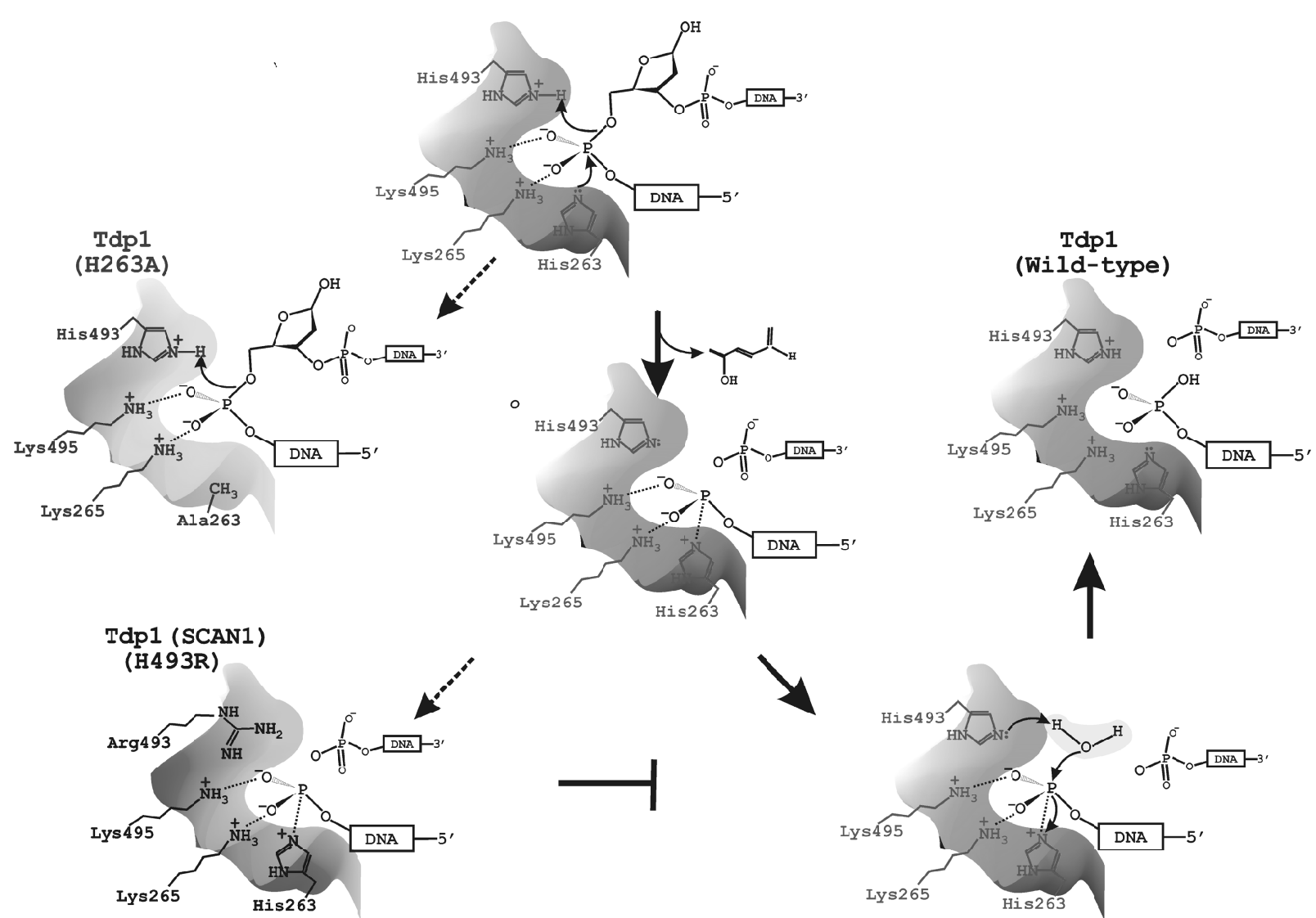

Fig. 2. The proposed mechanism of human Tdp1 and mutants (H263A) and H493R (SCAN1) interaction with AP site. Structure of Tdp1 active site modified from [2]

the 3 ' end of DNA. In addition to a tyrosine residue, the enzyme can hydrolyze 3' phosphodiester linkages involving short peptides, a nucleoside, an abasic residue, an artificial biotin adduct, and a glycolate moiety [5, 2426]. The feature common to all of these substrates is DNA, but there is a discrepancy between the biochemical and structural observations concerning whether the DNA molecule is single or double stranded. In a crystal structure containing oligonucleotide six bases in length, only the three nucleotides closest to the scissile phosphate are visible and they occupy a narrow groove extending away from the active site $[27,28]$.

To better understand the substrate features that are recognized by Tdp1, the size of either DNA or protein component of the substrate was varied by Interthal and Champoux [29]. Competition experiments and gel shift analyses comparing a series of substrates with DNA lengths increasing from 6 to 28 nucleotides indicated that, contrary to predictions based on the crystal structure of the protein, the apparent affinity for the substrate increased as the DNA length increased over the en- tire range tested. It has previously been found that a substrate containing the full-length native form of human topoisomerase I protein is not cleaved by Tdp1. The protein-oligonucleotide complexes containing either 53 or 108 amino acid long topoisomerase I-derived peptide were efficiently cleaved by Tdp1, but like the full length protein, a substrate containing 333 amino acid topoisomerase I fragment was resistant to cleavage. Finally, they have shown that the activity of the proteasome is required in vivo for the Tdp1 cleavage of topoisomerase I-DNA covalent complexes [29].

The reaction catalyzed by $\mathrm{Tdp} 1$ proceeds through a covalent intermediate in which an active site histidine (His263 in human Tdp1) is linked by a phosphamide bond to the DNA 3' phosphate from the substrate [30, 31]. The importance of Tdp1 in humans is highlighted by the observation that a recessive mutation in the human TDP1 gene is responsible for the inherited disorder, spinocerebellar ataxia with axonal neuropathy (SCAN1) [32] in which a H493R mutation in the TDP1 gene causes the accumulation of both Top1-DNA and 
Tdp1-DNA covalent intermediates in vivo [10,33-35]. The cells from SCAN1 patients are hypersensitive to the specific Top1 poison camptothecin and accumulate elevated Top1-associated DNA breaks in response to camptothecin $[5,10,36]$.

A catalytic mechanism proposed on the basis of the Tdp1 structure includes two histidine residues, namely His 263 and His493, in the active center [30, 31]. We checked two mutants of Tdp1 in which these histidines were replaced. In one of the mutants the histidine 493 was replaced to arginine (H493R). This mutation is responsible for the autosomal recessive neurodegenerative disease, SCAN1. In the second mutant, the histidine 263 was replaced to alanine (H263A). To analyze an involvement of these residues in the AP site hydrolysis we have analyzed binding to AP-DNA and activity in the reaction of AP site cleavage of two Tdp1 mutants. DNA binding experiments by using these mutant proteins indicate that both mutants can bind the AP site DNA as similar as the human Tdp1. However, using ssDNA and dsDNA structures containing the AP site we showed that both mutants did not reveal endonuclease activity obtained for wild-type Tdp1. On the basis of our data we proposed the mechanism of the AP site cleavage by Tdp 1 (Fig. 2).

Altogether, our results suggest that the AP site cleavage activity of human Tdp1 can be important to initiate the repair of AP sites. This activity was revealed in the context of cluster-type lesions when the AP sites are located nearby bulky lesions in DNA structure. Therefore this new activity of tyrosyl DNA-phosphodiesterase 1 can contribute to the repair of AP sites and this pathway is independent on the AP endonuclease 1 activity.

Acknowledgements. The authors are thankful to Dr. K. Caldecott (University of Sussex, Brighton) for providing us by recombinant plasmid coding Tdp1, to Dr. James Champoux (University of Washington, Seattle) for recombinant plasmid coding mutant Tdp1 (H263A) and to Dr. Sherif F. El-Khamisy (University of Sussex, Brighton) for providing us by recombinant plasmid coding mutant SCAN1 (H493R). This work was supported by the RFBR (11-04-00559, 12-04-00337); HRJRG-102; the Program of RAS Presidium «Molecular and Cellular Biology».

\section{Н. А. Лебедєва, Н. І. Речкунова, О. І. Лаврик}

Новий шлях ексцизійної репарації основ у ссавців за участі тирозил-ДНК-фосфодіестерази 1
Тирозил-ДНК-фосфодіестераза 1 (Тdр1) людини гідролізує 3'-фосфотирозильні зв'язки, які утворюються іп vіvо в результаті приєднання до ДНК-топоізомерази I (TopI). Тдр1 людини також здатна видаляти з 3'-кіния ДНК інші модифікувальні групи, включаючи 3'-фосфогліколати і залишки дезоксирибози, тобто функиіонувати як 3'-фосфодіестераза і фермент репарації. Недавно ми показали, що Tdp1 людини притаманна ще одна активність - вона може гідролізувати апуринові/апіримідинові (AP) сайти всередині ланцюга ДНК з утворенням 3'-кінцевого фосфату. АР-сайти ие одне з найчастіше виникаючих пошкоджень ДНК. Ключовим ферментом, який розщеплює АР-сайти, є апуринова/апіримідинова ендонуклеаза 1 (APE1). Проте в клітинах ссавиів існує шлях репарації, незалежний від APE1, у якому беруть участь ДНК-глікозилази. У даній роботі описано ще один АРЕ1-незалежний шлях penараиіï AP-сайтів за участі Tdp1. До повного ииклу репарації залучені полінуклеотидкіназа/фосфатаза, яка має 3'-фосфатазну активність, ДНК-полімераза та ДНК-лігаза.

Ключові слова: ексцизійна репарація основ, АР-сайт, тирозил-ДНК-фосфодіестераза 1.

\section{Н. А. Лебедева, Н. И. Речкунова, О. И. Лаврик}

Новый путь эксцизионной репарации оснований у млекопитающих с участием тирозил-ДНК-фосфодиэстеразы 1

Тирозил-ДНК-фосфодиэстераза 1 (Tdp1) человека гидролизует 3'фосфотирозильные связи, образуюшиеся іп vivo в результате присоединения к ДНК-топоизомеразе I (TopI). Tdp1 человека также способна удалять с 3'-конца ДНК другие модифицирующие групnы, включая 3'-фосфогликолаты и остатки дезоксирибозы, т. е. функиионировать как 3'-фосфодиэстераза и фермент репараuии. Недавно мы показали, что Tdp1 человека обладает еще одной активностью - она может гидролизовать апуриновые/апиримидиновые (АР) сайты внутри цепи ДНК с образованием 3'-кончевого фосфата. АР-сайты - это одно из наиболее часто возникаюших повреждений в ДНК. Ключевым ферментом, расщепляюшим AP-сайты, является апуриновая/апиримидиновая эндонуклеаза 1 (АРE1). Однако в клетках млекопитающих существует путь репарачии, независимый от АPE1, с участием ДНК-гликозилаз. В данной работе описан еще один АPE1-независимый путь репарации AP-сайтов с участием Tdp1. В полный цикл репарачии вовлечены полинуклеотидкиназа/фосфатаза, обладающая 3'-фосфатазной активностью, ДНК-полимераза и ДНК-лигаза.

Ключевые слова: эксиизионная репараџия оснований, АPсайт, тирозил-ДНК-фосфодиэстераза 1.

\section{REFERENCES}

1. Yang S. W., Burgin A. B. Jr., Huizenga B. N., Robertson C. A., Yao K. C., Nash H. A. A eukaryotic enzyme that can disjoin deadend covalent complexes between DNA and type I topoisomerases // Proc. Natl Acad. Sci. USA.-1996.-93, N 21.-P. 11534 11539.

2. Dexheimer T. S., Antony S., Marchand C., Pommier Y. TyrosylDNA phosphodiesterase as a target for anticancer therapy // Anticancer Agents Med. Chem.-2008.-8, N 4.-P. 381-389.

3. Barnes D. E., Lindahl T. Repair and genetic consequences of endogenous DNA base damage in mammalian cells // Annu. Rev. Genet.-2004.-38.-P. 445-476.

4. Wiederhold L., Leppard J. B., Kedar P., Karimi-Busheri F., Rasouli-Nia A., Weinfeld M., Tomkinson A. E., Izumi T., Prasad R., Wilson S. H., Mitra S., Hazra T. K. AP endonuclease-independent 
DNA base excision repair in human cells // Mol. Cell.-2004.15, N 2.-P. 209-220.

5. Interthal H., Chen H. J., Champoux J. J. Human Tdp1 cleaves a broad spectrum of substrates, including phosphoamide linkages // J. Biol. Chem.-2005.-280, N 43.-P. 36518-36528.

6. Hsiang Y. H., Hertzberg R., Hecht S., Liu L. F. Camptothecin induces protein-linked DNA breaks via mammalian DNA topoisomerase I // J. Biol. Chem.-1985.-260, N 27.-P. 14873-14878.

7. Nitiss K. C., Malik M., He X., White S. W., Nitiss J. L. TyrosylDNA phosphodiesterase (Tdp1) participates in the repair of Top2media ted DNA damage // Proc. Natl Acad. Sci. USA.-2006.103, N 24.-P. 8953-8958.

8. Dexheimer T. S., Stephen A. G., Fivash M. J., Fisher R. J., Pommier $Y$. The DNA binding and 3'-end preferential activity of human tyrosyl-DNA phosphodiesterase // Nucleic Acids Res.2010.-38, N 7.-P. 2444-2452.

9. Cortes Ledesma F., El Khamisy S. F., Zuma M. C., Osborn K., Caldecott $K$. W. A human 5'-tyrosyl DNA phosphodiesterase that repairs topoisomerase-mediated DNA damage // Nature.-2009.461, N 7264.-P. 674-678.

10. El-Khamisy S. F., Saifi G. M., Weinfeld M., Johansson F., Helleday T., Lupski J. R., Caldecott $K$. W. Defective DNA singlestrand break repair in spinocerebellar ataxia with axonal neuropathy-1 // Nature.-2005.-434, N 7029.-P. 108-113.

11. Plo I., Liao Z. Y., Barcelo J. M., Kohlhagen G., Caldecott K. W., Weinfeld M., Pommier Y. Association of XRCC1 and tyrosyl DNA phosphodiesterase (Tdp1) for the repair of topoisomerase I-mediated DNA lesions // DNA Repair (Amst).-2003.-2, N 10.P. 1087-1100.

12. Lebedeva N. A., Rechkunova N. I., Lavrik O. I. AP-site cleavage activity of tyrosyl-DNA phosphodiesterase 1 // FEBS Lett.2011.-585, N 4.-P. 683-686.

13. Lindahl T., Wood R. D. Quality control by DNA repair// Science.1999.-286, N 5446.-P. 1897-1905.

14. Mitra S., Hazra T. K., Roy R., Ikeda S., Biswas T., LockJ., Boldogh I., Izumi T. Complexities of DNA base excision repair in mammalian cells // Mol. Cells.-1997.-7, N 3.-P. 305-312.

15. Nash H. M., Bruner H. D., Scharer O. D., Addona T. A., Spooner E., Lane W. S., Verdine G. L. Cloning of a yeast 8-oxoguanine DNA glycosylase reveals the existence of a base-excision DNA-repair protein superfamily // Curr. Biol.-1996.-6, N 8.-P. 968-980.

16. Zharkov D. O., Shoham G., Grollman A. P. Structural characterization of the Fpg family of DNA glycosylases // DNA Repair (Amst.)-2003.-2, N 8.-P. 839-862.

17. Karimi-Busheri F., Daly G., Robins P., Canas B., Pappin D. J., Sgouros J., Miller G. G., Fakhrai H., Davis E. M., Le Beau M. M., Weinfeld M. Molecular characterization of a human DNA kinase // J. Biol. Chem.-1999.-274, N 34.-P. 24187-24194.

18. Karimi-Busheri F., Lee J., Tomkinson A. E., Weinfeld M. Repair of DNA strand gaps and nicks containing 3'-phosphate and 5'hydroxyl termini by purified mammalian enzymes // Nucleic Acids Res.-1998.-26, N 19.-P. 4395-4400.

19. Wilson D. M. 3rd. Processing of nonconventional DNA strand break ends // Environ. Mol. Mutagen.-2007.-48, N 9.-P. 772-782.

20. Chiang S. C., Carroll J., El-Khamisy S. F. TDP1 serine 81 promotes interaction with DNA ligase IIIalpha and facilitates cell survival following DNA damage // Cell Cycle.-2010.-9, N 3.P. 588-595.

21. El-Khamisy S. F. To live or to die: a matter of processing damaged DNA termini in neurons // EMBO Mol. Med.-2011.-3, N 2.P. 78-88.
22. Das B. B., Dexheimer T. S., Maddali K., Pommier Y. Role of tyrosyl-DNA phosphodiesterase (TDP1) in mitochondria // Proc. Natl Acad. Sci. USA.-2010.-107, N 46.-P. 19790-19795.

23. Nilsen L., Forstrom R. J., Bjoras M., Alseth I. AP endonuclease independent repair of abasic sites in Schizosaccharomyces pombe // Nucleic Acids Res.-2012.-40, N 5.-P. 2000-2009.

24. Liu C., Pouliot J. J., Nash H. A. Repair of topoisomerase I covalent complexes in the absence of the tyrosyl-DNA phosphodiesterase Tdp1 // Proc. Natl Acad. Sci. USA.-2002.-99, N 23.P. 14970-14975.

25. Inamdar K. V., Pouliot J. J., Zhou T., Lees-Miller S. P., RasouliNia A., Povirk L. F. Conversion of phosphoglycolate to phosphate termini on 3 ' overhangs of DNA double strand breaks by the human tyrosyl-DNA phosphodiesterase hTdp1 // J. Biol. Chem.2002.-277, N 30.-P. 27162-27168.

26. Povirk L. F. DNA damage and mutagenesis by radiomimetic DNA-cleaving agents: bleomycin, neocarzinostatin and other enediynes // Mutat. Res.-1996.-355, N 1-2.-P. 71-89.

27. Davies D. R., Interthal H., Champoux J. J., Hol W. G. Crystal structure of a transition state mimic for Tdp1 assembled from vanadate, DNA, and a topoisomerase I-derived peptide // Chem. Biol.-2003.-10, N 2.-P. 139-147.

28. Davies D. R., Interthal H., Champoux J. J., Hol W. G. Explorations of peptide and oligonucleotide binding sites of tyrosylDNA phosphodiesterase using vanadate complexes // J. Med. Chem.-2004.-47, N 4.-P. 829-837.

29. Interthal H., Champoux J. J. Effects of DNA and protein size on substrate cleavage by human tyrosyl-DNA phosphodiesterase 1 // Biochem. J.-2011.-436, N 3.-P. 559-566.

30. Interthal H., Pouliot J. J., Champoux J. J. The tyrosyl-DNA phosphodiesterase Tdp1 is a member of the phospholipase D super family // Proc. Natl Acad. Sci. USA.-2001.-98, N 21.-P. 1200912014.

31. Davies D. R., Interthal H., Champoux J. J., Hol W. G. Insights into substrate binding and catalytic mechanism of human tyrosyl-DNA phosphodiesterase (Tdp1) from vanadate and tungstate-inhibited structures // J. Mol. Biol.-2002.-324, N 5.-P. 917-932.

32. Takashima H., Boerkoel C. F., John J., Saifi G. M., Salih M. A., Armstrong D., Mao Y., Quiocho F. A., Roa B. B., Nakagawa M., Stockton D. W., Lupski J. R. Mutation of TDP1, encoding a topoisomerase I-dependent DNA damage repair enzyme, in spinocerebellar ataxia with axonal neuropathy // Nat. Genet.-2002.-32, N 2.-P. 267-272.

33. Interthal H., Chen H. J., Kehl-Fie T. E., Zotzmann J., Leppard J. B., Champoux J. J. SCAN1 mutant Tdp1 accumulates the enzymeDNA intermediate and causes camptothecin hypersensitivity // EMBO J.-2005.-24, N 12.-P. 2224-2233.

34. Hirano R., Interthal H., Huang C., Nakamura T., Deguchi K., Choi K., Bhattacharjee M. B., Arimura K., Umehara F., Izumo S., Northrop J. L., Salih M. A., Inoue K., Armstrong D. L., Champoux J. J., Takashima H., Boerkoel C. F. Spinocerebellar ataxia with axonal neuropathy: consequence of a Tdp1 recessive neomorphic mutation? // EMBO J.-2007.-26, N 22.-P. 4732-4743.

35. Katyal S., El-Khamisy S. F., Russell H. R., Li Y., Ju L., Caldecott $K$. W., McKinnon P. J. TDP1 facilitates chromosomal singlestrand break repair in neurons and is neuroprotective in vivo // EMBO J.-2007.-26, N 22.-P. 4720-4731.

36. Miao Z. H., Agama K., Sordet O., Povirk L., Kohn K. W., Pommier $Y$. Hereditary ataxia SCAN1 cells are defective for the repair of transcription-dependent topoisomerase I cleavage complexes // DNA Repair (Amst).-2006.-5, N 12.-P. 1489-1494. 